This is an electronic reprint of the original article. This reprint may differ from the original in pagination and typographic detail.

Author(s): Mäntynen, Anne; Shore, Susanna

Title: What is meant by hybridity? An investigation of hybridity and related terms in genre studies

Year: $\quad 2014$

Version:

Please cite the original version:

Mäntynen, A., \& Shore, S. (2014). What is meant by hybridity? An investigation of hybridity and related terms in genre studies. Text and talk, 34(6), 737-758.

https://doi.org/10.1515/text-2014-0022

All material supplied via JYX is protected by copyright and other intellectual property rights, and duplication or sale of all or part of any of the repository collections is not permitted, except that material may be duplicated by you for your research use or educational purposes in electronic or print form. You must obtain permission for any other use. Electronic or print copies may not be offered, whether for sale or otherwise to anyone who is not an authorised user. 


\title{
Anne Mäntynen and Susanna Shore* What is meant by hybridity? An investigation of hybridity and related terms in genre studies
}

\begin{abstract}
This article is an investigation and a discussion of hybridity and related terms as used in linguistic studies of genre. The theoretical points that are made are illustrated with data from empirical research done by others and with the authors' own data. The focus is on written texts but hybridity in spoken interaction is also discussed. The article defines the notion of genre and discusses (proto)typicality in relation to genre and hybridity. Recontextualization is also discussed. This is followed by a discussion of terms that have been used to talk about the processes of hybridity, firstly, as used in research that has mainly been done on spoken interaction. The focus then turns to terms that have mainly been used in research on written texts: sequential intertextuality, genre embedding, genre appropriation, genre blending, as well as terms referring to pervasive trends such as commodification. Terms that take a product-like perspective on hybridity are then discussed. First there is a discussion of terms, such as "macrogenre," which are used to describe the products of hybridization. This is followed by a discussion of genre chains and superordinate categories, such as "genre colonies," grouped together because of the hybridizing forces that permeate them.
\end{abstract}

Keywords: hybridity, genre blending, intertextuality, complexity, recontextualization, hybridizing processes

\section{Introduction}

Hybridity has been central to a lot of research in genre studies in recent years, and researchers have stressed its pervasiveness in the talk and in the written

\footnotetext{
*Corresponding author: Susanna Shore, Department of Finnish, Finno-Ugrian and Scandinavian Studies, University of Helsinki, Helsinki, Finland, E-mail: susanna.shore@helsinki.fi Anne Mäntynen, Department of languages, University of Jyväskylä, Jyväskylä, Finland, E-mail: anne.k.mantynen@jyu.fi
} 
texts that surround us (e.g., Bhatia 2000; Bhatia 2004; Sarangi 2000; Sarangi 2011; Fairclough 2003; Östman and Simon-Vandenbergen 2004; Swales 2004; Varghese and Abraham 2004; Kong 2006; Martin and Rose 2008; Solin 2008; Solin 2009; Lähdesmäki 2009; Catenaccio 2008). While the terms and concepts used by different researchers working in different research traditions are incommensurable - they are tied to theoretical assumptions that underlie the research, the nature of the spoken or written data, and the purposes for which the research has been carried out - they nevertheless overlap. Making links between different traditions is particularly important in a field that is becoming more and more fragmented.

As used in the title and throughout this article, hybridity is an umbrella term for all kinds of blending, mixing, and combining that occur in genres and texts. The purpose of the article is to discuss hybridity and the different kinds of hybridizing processes and products that have been distinguished by linguists studying genres from various perspectives. Our approach is thus not tied to a particular theory. Our main focus is on written texts but we shall also discuss hybridity in spoken interaction. The points that are made will be illustrated with data from empirical research done by others and with our own data.

The article is organized as follows. In Section 2, we shall define the notion of genre and discuss the notion of typicality, which underlies many discussions of genre and hybridity. We shall also briefly discuss the notion of recontextualization in relation to hybridity. Section 3 discusses terms used to talk about the processes of hybridity, firstly, as used in research that has mainly been done on spoken interaction, where the focus has recently been on simplicity versus complexity. Our discussion will then focus on terms that have mainly been used in research on written texts: sequential intertextuality, genre embedding, genre appropriation, and genre blending. In the remainder of the article, the focus is also on research that is based primarily on written texts and the perspective on hybridization is gradually widened. Section 4 discusses terms, such as "macrogenre," which are used to describe the products of hybridization. Section 5 deals with genre chains, which could be viewed as processes or as products. Section 6 looks at superordinate categories of genres, such as "genre colonies," grouped together because of the hybridizing forces that permeate them.

\section{Preliminary considerations}

Definitions of genre vary according to the focus of the research and the orientation of the researcher. The definition adopted in this article is one that underlies or is implied in many current views of genre in linguistics. From a linguistic 
point of view, a genre is a class or type of (spoken or written) text. From a social and collective point of view, a genre is a linguistically realized action or activity type or area of human activity (e.g., Bakhtin 1986; Miller 1984; Martin 1985: 250 ${ }^{1}$; Fairclough 1992: 126). From an individual and cognitive point of view, texts representing the same genre have a similar communicative purpose (or purposes) (e.g., Swales 1990; Bhatia 1993; Bhatia 2004: 23). Social and cognitive perspectives are complementary in that communicative purposes arise in (social) communities (cf. Swales 2004: 68-74).

Halliday and Hasan (2006), on the other hand, do not use the term genre but differentiate between situation types and registers. A situation type is a generalization based on actual situations. A register is viewed from dual perspectives. From the perspective of language use, a register is a text type, that is, a generalization based on actual texts. From the perspective of the language system, a register is a subpotential of language as (an inherently variable and dynamic) meaning potential. Seen in this way, a register is often discussed in terms of the meanings that are "at risk" (i.e., likely to occur) in a particular situational context (Halliday and Mathiessen 2013; Halliday and Hasan 2006; Hasan 2009). In a similar vein, Sarangi (e.g., 2011) distinguishes between activity types and discourse types, but for Sarangi discourse type covers not only registers but also interactional forms such as question-answer sequences, interruptions, and laughter.

Much of the research on written genres is centered on the overall organization or schematic structure of texts instantiating a genre (e.g., Eggins and Martin 1997; Martin and Rose 2008; Hasan 1989; Hasan 1996; Swales 1990; Paltridge 1997; Bhatia 1993), and many genre researchers have brought out the schematic structure variation associated with a particular genre (e.g., Ventola 1987; Hasan 1989; Hasan 1996; Nieminen 2010). Most researchers also focus on the semantic and lexicogrammatical features of texts, but there is variation in how this analysis is approached. Systemic functional linguists often present a detailed analysis of texts (e.g., Ventola 1987) or of a text instantiating a genre (e.g., Eggins and Martin 1997: 236), although - for illustrative purposes - analyses can be selective (e.g., Martin and Rose 2007; Martin and Rose 2008). ${ }^{2}$

1 Genre in Martin's model is, in fact, stratified (one stratum incorporating the subsequent strata): genre is realized by the contextual variables of field, tenor (participant relationships), and mode (the role of language and other semiotic systems), which in turn are realized by the linguistic choices in the text (e.g., Martin and Rose 2008).

2 Genres are not defined in terms of their lexicogrammatical features in Martin's approach. The lexis drawn on in a particular genre can vary according to field. Moreover, lexicogrammatical choices generally vary in the unfolding stages of a text. 
In work on genre done by other linguists, lexicogrammatical analysis is often more focused. Bhatia (1993), Bhatia (2004), and Swales (1990), for example, concentrate on the linguistic features that are significant in distinguishing the moves (or stages) in the organization of a text. ${ }^{3}$ The most selective lexicogrammatical analysis is done in computational and corpus-based studies, which generally focus on a few overall features of texts representing a genre (Biber 1995; Marco 2000; Hiltunen 2010; cf. Flowerdew 2005).

Whatever emphasis is given to the lexicogrammatical features of texts instantiating a genre, there must be some common features, otherwise we would not be able to recognize genres. Moreover, any notion of hybridity presupposes that there is a recognition that something is being blended, mixed, or shifted (cf. Sarangi forthcoming). For this reason, most genre researchers recognize or appeal to some notion of "typicality" or "prototypicality" in their discussion of genre and of hybridity (e.g., Sarangi 2000: 23, Sarangi forthcoming; Solin 2009; Lehti 2011: 1610).

The notion of typicality has been seen to be particularly important for the applications of linguistics, for example, in educational linguistics. Much of the work in systemic functional genre studies has been carried out with a view to teaching literacy skills to school children (Rose and Martin 2012: 3-4). Systemic functional researchers interested in pedagogical applications have stressed the qualitative analysis of a few texts "typical” of a particular genre, drawing on the expertise of core members in a given field (e.g., Martin and Rose 2007: 313). ${ }^{4}$

Martin and Rose (2007) use the term typical in an everyday sense; the term is not discussed nor is it listed in the index. Typicality as used by Martin and Rose can only be a cognitive notion in the sense that it is based on knowledge, since it is based on the teacher's or the researcher's notion of what is typical (and not on empirical research). In other words, language users have learnt to abstract from the variation associated with a genre and have some idea of what is at the core of genre (cf. Berkenkotter and Huckin [1993] for a sociocognitive perspective on typicality). ${ }^{5}$

3 Bhatia (1993; Bhatia 2004) differs from Swales (1990) in that he - in line with systemic functional linguists - does not tie a genre to a particular field.

4 Systemic functional linguists often distinguish between typology, distinguishing categories, and topology, looking at language in terms of prototypes and tendencies (e.g., Lemke 1999; Rose and Martin 2012: 83). The focus of most research is, however, on the former and on representing choices as a system network.

5 Selecting typical exemplars of a genre may be valid from a pedagogical perspective (cf. Bhatia 2004: 80), but this may mean that what actually is typical of the genre has been eliminated before the analysis begins. 
Typicality as used by Martin and Rose corresponds to what is referred to as "prototypicality" in cognitive or cognitively based approaches, inspired by the work of cognitive psychologists like Rosch (1977). Swales (1990: 48-58) describes genres in terms of their prototypical content and form. Paltridge's (1997: 106) definition of genre - as such - relies on the notion of a prototype: a genre is based on prototypical idea(lization)s of human communication patterns; these idealizations are derived from our knowledge of the interactional and conceptual properties of similar events. Similar to Paltridge's prototype is Nieminen's notion (2010) of a "neutral stereotype": a general image of what a lot of people believe to be typical of a particular genre. (The attribute "neutral" is used by Nieminen because the word "stereotype" has negative connotations.)

The notion of typicality, nevertheless, is also important for those who investigate texts in everyday and business (rather than educational) contexts and whose focus is on how genres mix and interact with each other. Bhatia (2004: 133-135), for example, discusses the mixed genre of the advertorial (advertisement + editorial) with an example from a vacation magazine about a holiday destination for golf enthusiasts. The word "typical" is repeated in Bhatia's analysis: the analysis is based on recognizing the typical characteristics of editorials and of advertisements.

In line with the scholars referred to in this section, we also see the need to refer to some notion of typicality in any discussion of genre and, indeed, of hybridity. On the other hand, like many of the scholars mentioned in this article, we also feel that an inherent property of many texts is the blending and mixing of genres in various ways (and this, in turn, is dependent on recognizing the features that are perceived to be typical of the genres that are represented in the blended text).

Another approach to hybridity and hybridization is to look at texts from the perspective of recontextualization. Bernstein (1996) originally used this term in his discussion of what happens in educational discourse, where academic research is transferred and transformed - selected, simplified, condensed, explained, and refocused - for pedagogic purposes. Linell (1998: 144-148) extends the notion of recontextualization to the shifting across time and space that happens in all discourses: recontextualization is the dynamic transference and transformation of some part or some aspect of a text (or text type) tied to a particular context to another text tied to another context. Linell applies the notion of recontextualization to subtle shifts within a text, such as shifts in the problem being addressed in doctor-patient interaction, ${ }^{6}$ and also to what are referred to as intertextual and interdiscursive phenomena (following

6 This could be seen as taking the notion to its extremity. 
Fairclough 1992). Intertextual recontextualization refers to the overt transfer and transformation of specific parts of one text to another; interdiscursive recontextualization refers to the transfer and transformation of more abstract features and conventions across texts or genres. These kinds of recontextualizations are reflected in hybridizing processes discussed in the next section.

\section{Hybridizing processes}

In this section we shall focus on how (parts of) a text representing one genre can be incorporated into another text representing another genre or mix of genres. We shall first consider hybridity as discussed in research that is mainly focused on spoken interaction. We include a section on spoken interaction because the phenomena studied are similar to those in written texts and they are interesting from the point of view of genre studies. We shall then deal with research that has been mainly focused on written texts and discuss what has been referred to as sequential intertextuality, genre embedding, and genre blending. We shall also deal with what has been referred to in systemic functional linguistics as a pretend genre or as contextual metaphor.

\subsection{Hybridity in spoken interaction}

Two early pioneers in genre research, Eija Ventola (1987) and Ruqaiya Hasan (1989), briefly refer to the incorporation of snippets of casual conversation or "small talk" in a service encounter. The following example is taken from more recent research on service encounters in Finnish.

(1) Kiosk (translated and simplified, Raevaara and Sorjonen 2006)

Salesperson: this one? [referring to a lotto system entry]

Customer: yeah.

Salesperson: ok.

(Goes to the cash register.)

anything else?

(Exchange of money.)

Customer: I don't think so

the weather has got quite cool

(Gives change to customer.)

Salesperson: well, it seems to be so

Customer: $\quad$ I should have worn a woollen cardigan

that's that then. 
Ventola (1987: 82-83) refers to small talk in service encounters as "genre-switching”; Hasan (1989) and Hasan (2009) refer to such elements as simply optional elements in the general structure potential. While it is relatively easy to distinguish small talk within a service encounter, it is not entirely clear how to characterize what is happening.

Raevaara and Sorjonen's (2006) research indicates that small talk in service encounters is not simply a matter of moving from one kind of social activity into another. Their analysis of 160 service encounters indicates that the small talk in these encounters is constrained not only by how well the participants know each other but also by the field of discourse. In quantitative terms, there is more small talk in kiosk encounters. This seems to be motivated by the frequency of contact and the fact that the participants know each other.

Moreover, and more importantly, small talk is integrated into the encounter in different ways. In the kiosk encounters, small talk is typically a separate sidetrack, unrelated to what is going on, as seen in example (1). In the social security office, on the other hand, small talk is without exception integrated into the ongoing activity. The customer in the following example is completing the filling out of a form in the presence of the claims representative:

(2) (Social security office, translated and simplified, Raevaara and Sorjonen 2006)

Customer:

it's the second of the month today, isn't it?

Claims representative: yeah

(Customer writes this on the form.)

Customer: the second, got to really think

about the month we're now in

Claims representative:

Customer:

Claims representative:

Claims representative: yeah, well it does really seem like summer when you look outside yeah heh [it's really warm now. [yeah, wonderful, well then, this is ready then ...

Example (2) illustrates how small talk in the social security office is tied into the actual service encounter. The customer is unsure about the date and the month, and this leads the claims representative to comment on the summer.

Examples (1) and (2) bring to mind the distinction that Hasan (1999; Hasan 2000) makes between independent and integrated "subtexts" in a "primary text" in her data on mother-child interaction: the small talk in (1) would be independent in Hasan's terms and in (2) the small talk is integrated. As in example (2), a mother-child dialogue can shift seamlessly from caregiving talk concerned with 
getting a child dressed to go out, to instructive talk about the use of an idiomatic expression, such as "silly goose" in English. Hasan's main distinction is between simple texts, such as a service encounter without small talk, and complex texts, such as examples (1) and (2). Hasan further distinguishes between various kinds of complexity.

Hasan (2000: 43-44) rejects the use of terms such as genre switching, genre combination, and hybridity. The terms are rejected because, for Hasan, they imply a static view of language in use and a predetermined combining of objects, much in the same way as peaches and plums have been hybridized into nectarines.

While metaphors borrowed from one discipline to another are always problematic, particularly if they are understood literally, there are other researchers who nevertheless use the term hybridity as a cover term for the blending, dynamic shifts, and complexities involved in meaning making in an ongoing interaction (as we do in this article).

A dynamic view of hybridity is taken by Sarangi (2011; Sarangi forthcoming), who has focused on interactional hybridity in professional healthcare settings. Sarangi distinguishes between simple and complex forms of hybridity. Simple and complex hybridity for Sarangi are tied to the number of roles activated in a role-set and the extent to which these roles align with the shifting roles of other participants in the interaction. An example of simple hybridity would be Hasan's example, referred to above, of a mother's caregiving talk shifting into instructive talk. In counseling encounters, hybridity is more likely to be complex. The role-set of a genetics counselor includes medical expert, therapist, educator, gatekeeper; the role-set of a client in a genetic counseling encounter may include woman, mother, single parent. Complexity arises when there are constant shifts in the role that is assumed by the counselor and constant adjustments to the role of the client. Sarangi's simple and complex hybridity, thus, would be complex from Hasan's perspective, since a primary text with even one subtext is regarded as a complex text by Hasan.

\subsection{Sequential intertextuality}

Hasan's notion of independency (as illustrated in example [1]) is reminiscent of what Fairclough (1992; Fairclough 1995) has referred to as sequential intertextuality in his early work. Sequential intertextuality means that a text can contain more or less easily distinguishable snippets from different genres and the 
snippets may even occur in a predictable sequence. Solin (2006) analyzes cosmetics advice columns in a women's magazine and demonstrates how they contain advice-giving and advertising stretches:

(3) Advice column (translated from Finnish, Solin 2006):

[ADVICE COLUMN:] Long hair especially should be combed straight only when the hair is dry. If you comb your hair when it is wet, it stretches and becomes brittle.

[ADVERTISEMENT:] If after washing it you spray your hair with Cutrin milk treatment, untangling the knots is easy.

Sequential intertextuality is not mentioned in Fairclough's later work (2003). The dropping of the term is understandable, since it is rare to find texts in which the snippets are, in fact, distinguishable and predictable (cf. blending, discussed in Section 3.5).

\subsection{Genre embedding}

A further step in the incorporation of a text representing one genre into a text representing another genre occurs when an entire text is incorporated as a clearly distinguishable part of another text. This is typical of school textbooks; for example, a foreign language textbook may contain (representations of) service encounter dialogues, newspaper articles, personal letters, etc. Indeed, educational discourse as a whole could be characterized by the importation of real-world genres into a pedagogic context, some of which are embedded, others incorporated and recontextualized in other ways (see Section 2).

Following Bhatia (1997), Lähdesmäki (2009: 378) refers to the incorporation of "blunder letters" from teenage magazines in an English as a Foreign Language (EFL) textbook as genre embedding. Fairclough (1992: 118) has referred to similar phenomena as embedded intertextuality. Embedding is also familiar from other genres. Figure 1 shows a familiar example of a recipe embedded in an advertisement, in this case a spaghetti recipe embedded in an advertisement for Crème Bonjour.

The use of the term embedding for examples like Figure 1 seems appropriate: genre embedding is analogous to the notion of syntactic embedding, where a clause functions as a part of another clause.

Embedding in texts, however, always involves recontextualization and the concomitant changes in meaning that is involved: a recipe in an advertisement 


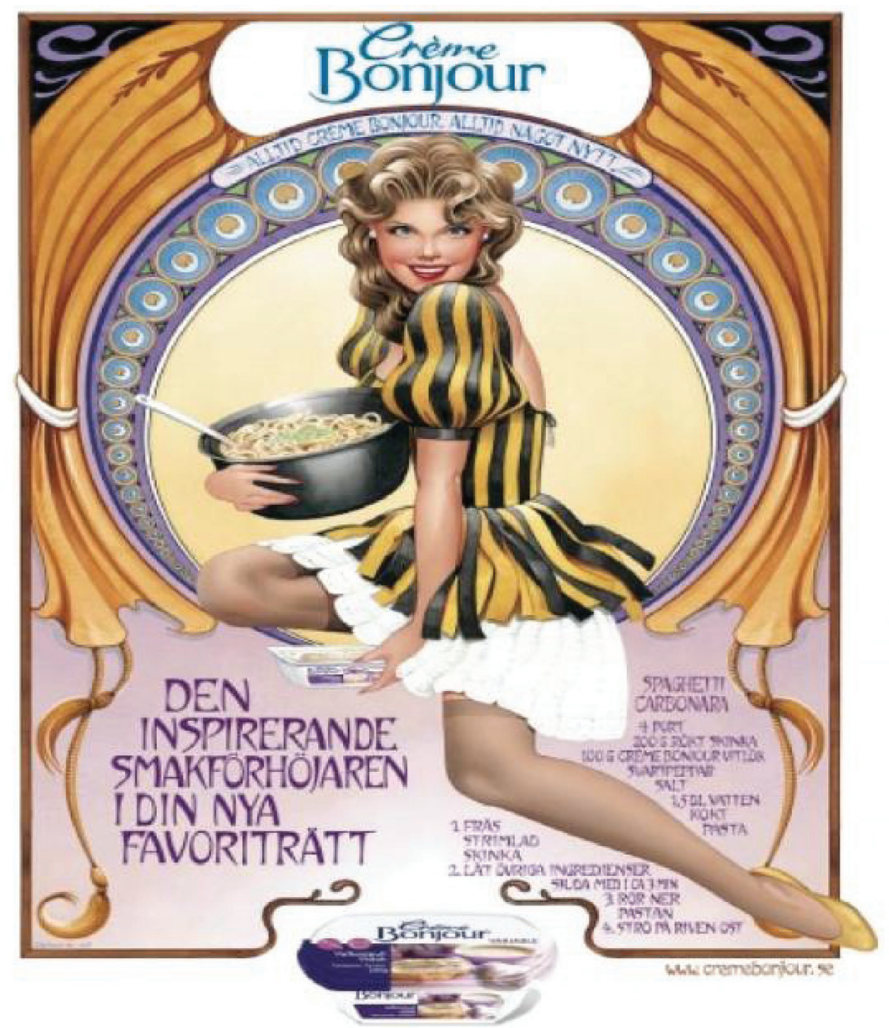

Figure 1: Recipe embedded in an advertisement (source: http://www.coloribus.com/adsarchive/ prints/creme-bonjour-cream-cheese-garlic-9500605)

with its references to the specific product being sold (Crème Bonjour) is put to the service of advertising. Embedding is often seen as a conventionalized and integral feature of many genres. Bhatia (2004: 79-80), for example, points out that letters, dialogues, reports, reviews, etc., are also commonly embedded in advertisements.

\subsection{Genre appropriation}

In embedding, there is no conflict between the experiential semantic content and the schematic structure of the text. In what we shall refer to as genre appropriation, a text appropriates the schematic structure of another genre. The following is an example of a music review published in a Finnish newspaper: 
(4) Music review translated from Finnish ${ }^{7}$

\section{EVANESCENCE}

Fallen

Epic

$2 \mathrm{dl}$ of Linkin Park without record players, especially a monotone male voice

$3 \mathrm{dl}$ female voice somewhere between Nightwish and Celine Dion

$2 \mathrm{dl}$ inoffensive guitar riffs

2 tbsp. glossily finished production solutions

1 tsp. electronic sound spices

Pour the ingredients into the record company's A\&R department and boil for the duration of 14 meetings. Filter the result through a couple of market surveys. Garnish with artistic and Gothic-like photographs. Serve to an unsuspecting audience.

The features of a music review and a recipe are obvious (cf. Mäntynen and Shore 2008).

The introduction of a new term for texts like this is justified in that the term is fairly transparent. Moreover, genre appropriation pinpoints a particular kind of mixing and a particular kind of meaning making: an entire text appropriates the form of a text representing another genre in order to exploit the meanings related to a particular generic form for a particular purpose, often for an ironic purpose as in example (4).

Genre appropriation has been discussed using other terms. Hasan's (1989: 98, 115-116) term pretend genre is illustrated with an example of an entire advertisement written as a letter and discussed in terms of the disassociation of generic form and function. ${ }^{8}$ Another term is Martin and Rose's (2008) somewhat esoteric-sounding contextual metaphor. Contextual metaphor is used to refer to instances in which one genre is deployed to stand for another: the reader is offered “a literal 'surface' reading implicating one genre, but providing in addition 'other genre' indicators signalling the presence of a deeper genre lurking behind" (Martin and Rose 2008: 248). Martin and Rose's example is of "Terra Nullius Pie," an ironic article from a student magazine written in the form of a recipe and giving instructions on how to strip a land of its natural resources and people.

7 Arttu Tolonen Nöjesguiden 6/2003.

8 Hasan's term "pretend genre" is not employed here because with texts like example (4) it is not really a question of a genre pretending to be another but of a text belonging to one genre assuming the guise of another genre. 
However, contextual metaphor is also used by Martin and Rose (2008: 248) in reference to a text written by a primary school pupil in a Socratic question and answer format. The actual text is not included in Martin and Rose's book but, according to them, the text was written as a report of a trip to the library. While a question and answer format does not constitute a genre and, thus, does not point to another genre "lurking behind," the term contextual metaphor is used because the pupil's report involves a recontextualization of a format that is typical of other contexts, which is the idea behind the notion on contextual metaphor. ${ }^{9}$

\subsection{Genre blending}

In addition to the processes of hybridization discussed so far, there are ways of deploying the resources of various genres in a text in such a way that the boundaries between the genres are not clear-cut. This process has been called genre mixing, blurring, bending, and hybridization (Bhatia 1997; Bhatia 2004; Fairclough, 2003; Herring et al. 2004; Varghese and Abraham 2004; Kong 2006; Solin 2006; Catenaccio 2008). We shall use the term genre blending since we use hybridization and mixing as cover terms for all of the phenomena that are discussed in this article.

Genre switching, genre embedding, and genre appropriation generally result in texts that mix different genres but maintain their original genre identity: a service encounter with snippets of casual conversation is still a service encounter and not a casual conversation; an advertisement that has a recipe embedded in it is still an advertisement and not a recipe; and a music review written in the format of a recipe is still a review and not a recipe. Genre blending, on the other hand, results not only in texts that combine features of two or more genres, but it generally results in texts with an ambivalent generic status and/or it results in the development of new genres.

A good example is the following text excerpt from a series of books which the publishers refer to as a reference library for Finnish children. It is from an

\footnotetext{
9 If metaphor is seen as the transference of a literal meaning to another context (Greek metapherein "to transfer"), contextual metaphor involves transference in that the format associated with one context (e.g., the format of a recipe) is transferred to another context (e.g., the context of reviewing music). Thus it is a specific kind of recontextualization.
} 
article entitled "Fertilization," which in turn is included in the volume entitled "People."

(5) (Children's encyclopedia, translated from Finnish) ${ }^{10}$

\section{Fertilization}

There are about 160 children born each day in Finland. Although birth is an everyday event, the beginning of a new life is always the result of coincidences and a miracle. One of the miracles is whether the baby will be a boy or a girl.

In order for a baby to be born, its mother and father have to fondle each other by making love.

Making love is also referred to as sexual intercourse because people are together and so close to each other that two people become almost like one.

In sexual intercourse the man pushes his penis ... [followed by a fairly explicit description of sexual intercourse and ejaculation].

The sperm contains millions of tiny sperm cells, which look a little bit like tadpoles. The birth of a new life is quite a coincidence, as all the sperm swim competitively to the egg cell, which is released only once a month, and try to penetrate it. Only one sperm makes it.

The moment at which the egg cell and the sperm cell combine into a single new cell is called fertilization.

A man has two kinds of sex cells: X and Y sperm cells. A woman on the other hand only has one kind, $\mathrm{X}$ egg cells. The fertilizing sperm type determines the sex of the child that will be born ... [followed by an account of genes and then of developments in the mother's womb].

Sex is part of adult life, but before you start to have sex, you need to be very aware of how to prevent pregnancy and sexually transmitted diseases.

The text incorporates features that can be related to a number of genres. The genre of a scientific report is reflected, for example, in the use of the generic present tense to describe biological processes and the taxonomies that are set up ("two kinds of sex cells: X and Y"). The textbook as well as other school genres are reflected in the way in which factual scientific information is related to the everyday world (e.g., "sperm cells, which look a little bit like tadpoles”). Sex

10 Tietoretki. Lasten tietokirjasto [A knowledge journey: A reference library for children]. Helsinki: Weilin + Göös, 2005. 
guides for children are drawn upon in the explicit description of sexual intercourse. This aspect of the text is reinforced by a separate text in a banner at the bottom of the page ("Sex is part of adult life, but before you start to have sex..."). The blending that occurs in the text reflects its multiple purposes and makes it hard to assign it to any one particular genre.

Genre blending can result in generic change and new genres, which in turn can gradually become established and conventionalized; thus, it is tied to issues related to the (relative) stability of genres (Fairclough 1989; Fairclough 1992; Fairclough 2003; Bhatia 2004; Varghese and Abraham 2004; Kong 2006; Solin 2006; Solin 2009; Catenaccio 2008). Varghese and Abraham (2004), for example, analyze what they refer to as "book-length scholarly essays," such as Steven Pinker's The Language Instinct and Howard Gardner's Frames of Mind, in which academics make their research and their theories more accessible to the general public. The essays are directed not only at a lay audience, including academics who are not experts in the field in question, but also at students and colleagues within the same field.

The term hybridity (or mixing) has also been used in relation to intertextuality and interdiscursivity (discussed in Section 2). Kong (2006) applies the concept of intertextuality in an analysis of property transaction reports in newspapers: a hybrid genre is construed through the mixing of voices, intertextuality, and the mixing of two practices (journalistic reporting and selling properties).

Intertextuality in itself, however, does not necessarily lead to a hybrid genre. Ravotas and Berkenkotter (1998), for example, deal with intertextuality in psychotherapeutic assessments, which are based on written notes taken by a psychotherapist when she interviewed a client. The assessment transforms the client's life experiences, so that the voice of the client (relating the client's life experiences) is subsumed into the voice of the therapist.

Ravotas and Berkenkotter (1998: 217-218) do not use the term hybridity but they do refer to recontextualization as well as to the "blending of voices" and to the "integrating" of one text into another. The phenomenon discussed in Ravotas and Berkenkotter's article takes us to limits of hybridity, at least from the point of view of genre studies. The incorporation of other texts into one's own texts is a fundamental property of all texts. This is what Fairclough (1992) refers to as interdiscursivity (also referred to by Fairclough as constitutive intertextuality). Moreover, Ravotas and Berkenkotter are concerned with what has happened in the same professional practice (psychotherapy), whereas Kong (as discussed in the previous paragraph) deals with different practices (journalistic reporting and selling properties) and the development of new genres. ${ }^{11}$

11 The notion of voice, as based on the work of Bakhtin (e.g., 1984), is of course central to many studies not only in discourse analysis in linguistics but also in other disciplines. Bartlett 
General trends could also be seen in terms of blending. A particularly prevalent type of general blending is advertising: it takes over other genres so that genres that are not primarily concerned with selling goods (in a concrete sense) are produced as though they were. Bhatia's (2004: 57-58) examples include film reviews and company reports; Fairclough (1992: 207-210) looks at a university prospectus. Various kinds of pervasive and expansive blending have been distinguished: colonization (Fairclough 1992; Bhatia 2004: 57-58), commodification, conversationalization, and technicalization (Fairclough 1992: Ch. 7).

\section{The products of hybridization}

In the previous section, we looked at terms that have been used to refer to hybridizing processes. The focus of this section is on terms that have been used primarily to refer to the products of hybridization in writing.

The term hybrid (or mixed) genre is typically used for the products of genre blending (see Section 3.5) which constitute new and emerging genres: Varghese and Abraham's (2004) book-length scholarly essay and Bhatia's (2004) advertorial. Catenaccio (2008), however, also regards a press release as a hybrid genre combining reporting and self-promotion (advertisement), even though advertising and promotion have long been common properties of press releases.

Hybrid genres can be distinguished from what Bakhtin (1986: 62) in his classic essay on speech genres refers to as secondary or complex genres.

Secondary (complex) speech genres - novels, dramas, all kinds of scientific research, major genres of commentary, and so forth - arise in more complex and comparatively highly developed and organized cultural communication (primarily written) that is artistic, scientific, socio-political, and so on. During the process of their formation, they absorb and digest various primary (simple) genres that have taken form in unmediated speech communion. (Bakhtin 1986: 62)

The term complex genre corresponds to what Martin and Rose (2008) refer to as a macrogenre. Macrogenres are "larger texts" that are "made up of short genres" (Martin and Rose 2008; Rose and Martin 2012: 178, 331). Examples given by Martin and Rose (2008) include school textbooks; for example, the foreign language textbook mentioned earlier or a history textbook that may include

(2012: 19), for example, uses the term "hybrid voice" in his analysis of intercultural discourse: a hybrid voice is one that builds a bridge between two cultures. However, the complex notion of voice is beyond the scope of this article. 
sections that are biographical, explanatory, or descriptive. Martin (2009) also illustrates the notion of a macrogenre with an extract from Mandela's autobiography, which starts as a report generalizing the cost of freedom and then turns into a story. A macrogenre, thus, results from both embedding and blending.

The term super-genre has also been used for what could be seen as a variant of a macrogenre or complex genre. In an analysis of blogs written by French politicians, Lehti (2011) regards the blog as a super-genre, a politician's blog as a genre, and the types of texts that constitute the genre - diary, scrapbook, noticeboard, essay, and polemic - as subgenres. This deploying of other genres as an integral and conventionalized feature of a particular genre is akin to the examples discussed in Section 3.4, where texts are appropriated for ironic purposes (e.g., the review of Evanescence, Terra Nullius Pie) or to mislead a gullible reader (advertisement written as a letter).

\section{Genre chains}

The term hybridization (or mixing) has also been used in conjunction with what have been referred to as genre chains or intertextual chains. We discuss chains at this point in the article because they have been approached both as a process (the process of chaining texts in a chain) and as a product (a set of texts representing different genres forming a chain).

These chains occur when prior texts (representing one genre) get incorporated into other texts (representing other genres) so that there is a fairly largescale recontextualization of (mostly experiential) semantic features from one text to another in temporal succession. For example, a news report, is often based on a press release, which in turn may be based on a report written by an expert. The genres involved in the chain are thus regularly dependent on each other (Iedema 1999; Solin 2001; Solin 2004; Fairclough 2003; Berkenkotter and Hanganu-Bresch 2011).

In an analysis of genre chains of an environmental debate on air pollution risks in the United Kingdom, Solin (2004) demonstrates how micro-level meaning shifts are framed and constrained by genres and institutions in a genre chain. On the one hand, since the genres involved in genre chains are influenced by each other, they are products of constant hybridization. On the other hand, genre chains are also conventionalized sites for (inter)textual interaction between texts and genres, and therefore are also sites for processes of hybridization.

Genre change can result from the interdependence of genres in a chain, and in particular, from the fact that one genre anticipates another genre. For 
example, most press releases these days are written so that they can be easily rewritten as a news article (Jacobs 1999; Kankaanpää 2001; Kankaanpää 2006).

A related phenomenon has been referred to as a genre suite by Berkenkotter and Hanganu-Bresch (2011) in their analysis of documents used in nineteenthcentury psychiatry to confine people to mental asylums. The document in question consists of four texts written sequentially by different people, each of which "invites" the following text. The uptake of the entire genre suite depends on the uptake of each text in succession. This kind of genre suite seems to be typical of institutional genres.

\section{Superordinate genre categories}

Another perspective on hybridity is offered by superordinate categories. Superordinate categories have been proposed for both genres characterized by the kind of pervasive blending discussed at the end of Section 3.5 and for genres (e.g., stories) that become recontextualized in many contexts.

Bhatia (2004) uses the term genre colony to refer to the products of colonization (see the end of Section 3.5). Colonies of related genres include promotional genres (advertisement, sales promotion, book blurb, etc.) and reporting genres (annual report, newspaper report, medical report, scientific report, etc.). Grouping genres together in this way is an attempt to capture the dynamic nature of genres and the relations between them as well as to explain the way in which genres mix and interact with each other.

Fairclough talks about "pre-genres" such as narratives (Fairclough 2003: 68-69; cf. Swales 1990: 61) and "disembedded genres" such as an interview, both of which occur in very many different contexts. These, particularly the latter, are like Bhatia's colonies in that they are expansive.

A narrative is an abstract category that, according to Fairclough, "transcends" particular networks of social practices. It can be a story in a casual conversation, a story in the press, or a story told by a client in therapy, each of which is tied to specific social practices. ${ }^{12}$ Distinct from a pre-genre, according to Fairclough, is a "disembedded genre," such as an interview. A disembedded genre is less abstract than a pre-genre; rather than transcending particular

12 Rose and Martin (2012: 128-130) use the term genre family to refer to the grouping of genres (including stories) for pedagogical purposes. 
networks of social practices it is borrowed from one set of practices to the next. If a job interview is taken as the paradigm case of an interview, then this could be described as a face-to-face situation designed to elicit information from a potential employee. This format has then been borrowed, inter alia, to celebrity interviews on television (i.e., interviews designed to elicit information about the interviewee) and to ethnographic interviews (i.e., interviews designed to elicit information from informants). They can also be recontextualized in the form of written texts in magazines and scientific articles.

\section{Concluding remarks}

This article has looked at terms and concepts related to hybridity and has attempted to tease out the different kinds of hybridizing processes and products that have been distinguished by researchers (primarily those working in genre studies). As terms are not always clearly defined in the original research, we have tried to give clear definitions and clear examples. In this way, we hope to make links among various research traditions.

Section 2 of this article defined the notion of genre and discussed the importance of (proto)typicality in any discussion of genre and of hybridity. The focus in Section 3 was on discussing the processes of hybridization as they have been identified in research on spoken interaction and written texts. This is not to deny that in any one text these processes may be combined as well as remain fuzzy or blurred. Section 4 discussed the terms that have been used to refer to the products of hybridization in research on written texts: hybrid genres, complex genres, macrogenres, and super-genres. Section 5 focused on genre chains. Finally in Section 6 we briefly discussed superordinate categories, which take a very broad perspective on the way in which texts and genres are mixed and become recontextualized.

As indicated in the introduction to this article, many of the differences not only stem from the theoretical orientation of the researcher, but are also dependent on the nature of the data. Researchers working on spoken data often focus on the dynamics of hybridity; researchers on written language are more likely to consider genres in terms of their relative stability, a perspective which is an essential basis for teaching genres in educational institutes. Our approach has been descriptive rather than prescriptive. However, we hope that an account of how the various terms related to hybridity have been employed in previous research will provide coordinates for the appropriate use of these terms in future research. 


\section{References}

Bakhtin, Mihail. 1984. Problems of Dostoevsky's poetics, Caryl Emerson (ed. \& trans.). Minneapolis, MN: University of Michigan Press.

Bakhtin, Mihail. 1986. The problem of speech genres. V. W. McGee (trans.). In Caryl Emerson \& Michael Holquist (eds.), Speech genres and other late essays, 60-102. Austin, TX: University of Texas Press.

Bartlett, Tom. 2012. Hybrid voices and collaborative change: Contextualising positive discourse analysis. London: Routledge.

Berkenkotter, Carol \& Cristina Hanganu-Bresch. 2011. Occult genres and the certification of madness in a 19th-century lunatic asylum. Written Communication 28(2). 220-250.

Berkenkotter, Carol \& Thomas N. Huckin. 1993. Rethinking genre from a sociocognitive perspective. Written Communication 10(4). 475-509.

Bernstein, Basil. 1996. Pedagogy, symbolic control and identity. London: Taylor \& Francis.

Bhatia, Vijay K. 1993. Analysing genre: Language use in professional settings. London: Longman.

Bhatia, Vijay K. 1997. Genre-mixing in academic introductions. English for Specific Purposes 16. 181-195.

Bhatia, Vijay K. 2000. Genres in conflict. In Anna Trosborg (ed.), Analysing professional genres, 149-161. Amsterdam \& Philadelphia, PA: Benjamins.

Bhatia, Vijay K. 2004. Worlds of written discourse: A genre-based view. London: Continuum.

Biber, Douglas. 1995. Dimensions of register variation: A cross-linguistic comparison. Cambridge: Cambridge University Press.

Catenaccio, Paola. 2008. Press releases as a hybrid genre: Addressing the informative/promotional conundrum. Pragmatics 18. 9-31.

Eggins, Suzanne \& J. R. Martin. 1997. Genres and registers of discourse. In T. van Dijk (ed.), Discourse as structure and process (Discourse Studies 1), 230-256. London: Sage.

Fairclough, Norman. 1989. Language and power. London: Longman.

Fairclough, Norman. 1992. Discourse and social change. Cambridge: Polity Press.

Fairclough, Norman. 1995. Media discourse. London: Edward Arnold.

Fairclough, Norman. 2003. Analysing discourse: Textual analysis for social research. London: Routledge.

Flowerdew, Lynne. 2005. An integration of corpus-based and genre-based approaches to text analysis in EAP/ESP: Countering criticisms against corpus-based methodologies. English for Specific Purposes 25. 321-332.

Halliday, M. A. K. \& Ruqaiya Hasan. 2006. Retrospective on SFL and literacy. In Rachel Whittaker, Mick O'Donnell \& Anne McCabe (eds.), Language and literacy: Functional approaches, 15-44. London: Continuum.

Halliday, M. A. K. \& Christian M. I. M. Matthiessen. 2013. Halliday's introduction to functional grammar, 4th edn. London: Routledge.

Hasan, Ruqaiya. 1989. The structure of a text. In M. A. K. Halliday \& Hasan Ruqaiya (eds.), Language, context, and text: Aspects of language in a social-semiotic perspective, 52-69. Oxford: Oxford University Press.

Hasan, Ruqaiya. 1996. The nursery tale as a genre. In C. Cloran, D. Butt \& G. Williams (eds.), Way of saying: Ways of meaning: Selected papers of Ruqaiya Hasan, 51-72. London: Cassell. 
Hasan, Ruqaiya. 1999. Speaking in reference to context. In Mohan Ghadessy (ed.), Text and context in functional linguistics, 219-328. Amsterdam \& Philadelphia, PA: Benjamins.

Hasan, Ruqaiya. 2000. The uses of talk. In Srikant Sarangi \& Malcolm Coulthard (eds.), Discourse and social life, 28-47. Harlow: Pearson.

Hasan, Ruqaiya. 2009. The place of context in a systemic functional model. In M. A. K. Halliday \& Jonathan J. Webster (eds.), Continuum companion to systemic functional linguistics, 166-189. London: Continuum.

Herring, Susan C., Lois Ann Scheidt, Sabrina Bonus \& Elijah Wright. 2004. Bridging the gap: A genre analysis of weblogs. In Proceedings of the 37th Hawaii International Conference on System Science. http://ba-projekt.pbworks.com/f/herring.pdf (accessed 10 October 2011).

Hiltunen, Turo. 2010. Grammar and disciplinary culture: A corpus-based study. Jyväskylä: Bookwell. http://urn.fi/URN:ISBN:978-952-10-6464-7 (accessed 13 October 2011).

ledema, Rick. 1999. Formalising organisational meaning. Discourse \& Society 10(1). 49-65.

Jacobs, Geert. 1999. Preformulating the news. An analysis of the metapragmatics of press releases. Amsterdam \& Philadelphia, PA: John Benjamins.

Kankaanpää, Salli. 2001. From letters to news reports: Diachronic changes in Finnish municipal press releases 1979-1999. In W. Vagle \& K. Wikberg (eds.), New directions in Nordic text linguistics and discourse analysis: Methodological issues, 229-242. Oslo: Novus.

Kankaanpää, Salli. 2006. Hallinnon lehdistötiedotteiden kieli [The language of administrative press releases]. Helsinki: Finnish Literature Society.

Kong, Kenneth C. C. 2006. Property transaction report: News, advertisement or a new genre? Discourse Studies 8. 771-796.

Lähdesmäki, Salla. 2009. Intertextual analysis of Finnish EFL textbooks: Genre embedding as recontextualization. In Charles Bazerman, Adair Bonini \& Débora Figueiredo (eds.), Genre in a changing world, 375-392. Parlor Press online. http://wac.colostate.edu/books/genre (accessed 23 January 2014)

Lehti, Lotta. 2011. Blogging politics in various ways: A typology of French politicians' blogs. Journal of Pragmatics 43(6). 1610-1627.

Lemke, J. L. 1999. Typological and topological meaning in diagnostic discourse. Discourse Processes 27(2). 173-185.

Linell, Per. 1998. Discourse across boundaries: On recontextualizations and the blending of voices in professional discourse. Text 24(3). 143-157.

Mäntynen, Anne \& Susanna Shore. 2008. Tekstilajien lumo [The fascination of genres]. In Tiina Onikki-Rantajääskö \& Mari Siiroinen (eds.), Kieltä kohti, 24-33. Helsinki: Otava.

Marco, Maria José Luzon. 2000. Collocational frameworks in medical research papers: A genre-based study. English for Specific Purposes 19. 63-86.

Martin, J. R. 1985. Process and text: Two aspects of human semiosis. In J. D. Benson \& W. S. Greaves (eds.), Systemic perspectives on discourse: Selected theoretical papers from the 9th International Systemic Workshop, 248-274. Norwood, NJ: Ablex.

Martin, J. R. 2009. Genre and language learning: A social semiotic perspective. Linguistics and Education 20. 10-21.

Martin, J. R. \& David Rose. 2007. Working with discourse: Meaning beyond the clause. London: Continuum.

Martin, J. R. \& David Rose. 2008. Genre relations: Mapping culture. London: Equinox.

Miller, Carolyn R. 1984. Genre as social action. Quarterly Journal of Speech 70. 151-167. 
Nieminen, Tommi. 2010. Lajien synty: Tekstilaji kielitieteen semioottisessa metateoriassa [The origin of species: Genre in semiotic metatheory in linguistics]. Jyväskylä: University of Jyväskylä Press.

Östman, Jan-Ola \& Anne-Marie Simon-Vandenbergen (eds.). 2004. Media discourse: Extensions, mixes and hybrids. [Special issue]. Text 24(3).

Paltridge, Brian. 1997. Genre, frames and writing in research settings. Amsterdam \& Philadelphia, PA: Benjamins.

Raevaara, Liisa \& Marja-Leena Sorjonen. 2006. Vuorovaikutuksen osanottajien toiminta ja genre: Keskustelunanalyysin näkökulma [The action of interactants and genre: A conversational analytic perspective]. In Anne Mäntynen, Susanna Shore \& Anna Solin (eds.), Genre - tekstilaji [Genre - text kind], 122-150. Helsinki: Finnish Literature Society.

Ravotas, Doris \& Carol Berkenkotter. 1998. Voices in the text: The uses of reported speech in a psychotherapist's notes and initial assessment. Text 24(3). 211-239.

Rosch, Eleanor. 1977. Human categorisation. In N. Warren (ed.), Advances in cross-cultural psychology, vol. 1, 1-72. London: Academic Press.

Rose, David \& J. R. Martin. 2012. Learning to write, reading to learn: Genre, knowledge and pedagogy in the Sydney school. Sheffield: Equinox.

Sarangi, Srikant. 2000. Activity types, discourse types and interaction hybridity: The case of genetic counselling. In Srikant Sarangi \& Malcolm Coulthard (eds.), Discourse and social life, 1-27. Harlow: Pearson.

Sarangi, Srikant. 2011. Role hybridity in professional practice. In Srikant Sarangi, Vanda Polese \& Giuditta Caliendo (eds.), Genre(s) on the move: Hybridisation and discourse change in specialised communication, 271-296. Napoli: Edizioni Scientifiche Italiane.

Sarangi, Srikant. Forthcoming. Activity types, discourse types and role types: Interactional hybridity in professional-client encounters. In D. R. Miller \& P. Bayley (eds.), Hybridity in systemic functional linguistics: Grammar, text and discursive context. Sheffield: Equinox.

Solin, Anna. 2001. Tracing texts: Intertextuality in environmental discourse. Helsinki: Department of English, University of Helsinki.

Solin, Anna. 2004. Intertextuality as mediation: On the analysis of intertextual relations in public discourse. Text 24(2). 267-296.

Solin, Anna. 2006. Genre ja intertekstuaalisuus [Genre and intertextuality]. In Anne Mäntynen, Susanna Shore \& Anna Solin (eds.), Genre - tekstilaji [Genre - text kind], 72-95. Helsinki: Finnish Literature Society.

Solin, Anna. 2008. The teaching portfolio as a hybrid genre: Local and global influences. In M. Garant, I. Helin \& H. Yli-Jokipii (eds.), Kieli ja globalisaatio - Language and globalization (AFinLAn Yearbook 2008), 359-380. Jyväskylä: Publications of the Applied Linguistics Association of Finland.

Solin, Anna. 2009. Genre. In Jan-Ola Östman \& Jef Verschueren (eds.), Handbook of pragmatics. Amsterdam \& Philadelphia, PA: Benjamins.

Swales, John M. 1990. Genre analysis: English in academic and research settings. Cambridge: Cambridge University Press.

Swales, John M. 2004. Research genres: Exploration and applications. Cambridge: Cambridge University Press.

Varghese, Susheela Abraham \& Sunita Anne Abraham. 2004. Book-length scholarly essays as a hybrid genre in science. Written Communication 21(2). 201-231.

Ventola, Eija. 1987. The structure of interaction: A systemic approach to the semiotics of service encounters. London: Frances Pinter. 


\section{Bionotes}

\section{Anne Mäntynen}

Anne Mäntynen received a PhD in Finnish language from the University of Helsinki. Her PhD thesis (2003) is a genre analysis of popular language columns. She is currently acting professor of Finnish at the University of Jyväskylä. She has published on discourse studies. She is the editor in chief of Virittäjä (the Finnish linguistic journal).

\section{Susanna Shore}

Susanna Shore received a PhD in linguistics from the School of English and Linguistics, Macquarie University, Sydney. Her PhD thesis (1992) is a systemic functional description of central grammatical features of Finnish. She is currently a senior lecturer and docent (adjunct professor) in Finnish at the University of Helsinki. She has published on various aspects of Finnish grammar and discourse analysis. 